\title{
National-cultural identity and development of cultural identity of the population of Stavropol Territory
}

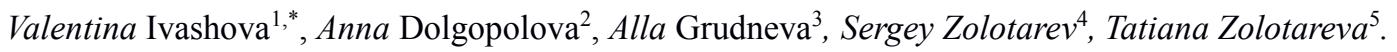 \\ ${ }^{1}$ Candidate of Social Sciences, Docent, Docent of Project Management Department of Stavropol State Agrarian University, 355017, \\ Stavropol, Russia \\ 2 Candidate of Economic Sciences, Docent, Docent of Mathematics Department of Stavropol State Agrarian University, 355017 , \\ Stavropol, Russia \\ ${ }^{3}$ Candidate of Economic Sciences, Docent, Docent of Taxation and Financial law Russian State Agrarian University named after K. A. \\ Timiryazev, 127550, Moscow, Russia \\ ${ }^{4}$ Doctor of Philosophy, Associate Professor, Department of Philosophy and History, Stavropol State Agrarian University, Stavropol, \\ 355017, Russia \\ ${ }^{5}$ Post-graduate student of North Caucasus Federal University, Department of Philosophy, 355029, Stavropol, Russia
}

\begin{abstract}
The article considers the results of the research of the national and cultural identity of the population of the Stavropol Territory. The analysis of representations of inhabitants of the territory of the South of Russia about their national identity and the role of cultural attributes defining this identification has been carried out. The factors influencing the development of cultural identity of the population have been studied.
\end{abstract}

\section{Introduction}

Trends, regularities, problems and contradictions of socio-political relations with a certain periodicity highlight certain factors that, on the one hand, are the result, and on the other hand, act as catalysts for social development. Among such factors national and cultural self-determination of peoples is highlighted, the actualization of which is most vigorously taking place at the stage of socio-economic and political reform of the state. National and cultural self-determination ensures the embodiment of the identity of groups and communities, the identity of a person and a citizen. National-cultural self-determination is a component of the general civil culture in the system of civil identity.

Due to a significant number of social practices of ethnic and cultural interaction the issue of national and cultural identity and the harmonious development of the cultural identity of the population is relevant for the multi-ethnic Stavropol Territory. In order to ensure a positive impact on this important part of the social sphere, we need a balanced policy and consolidation of the efforts of such institutions as culture, education, state and municipal authorities.

To understand the situation in the sphere of ethnic and cultural interaction of the population of the Stavropol Territory, it is vital to study the national and cultural identity and determine the ways of harmonious development of the cultural identity of the population of the region.

\footnotetext{
*Corresponding author: vivashov@mail.ru
}

Therefore, the purpose of the sociological research is to analyze the national and cultural identity of the population of the Stavropol Territory and to determine the impact of cultural policies carried out in the region on the development of cultural identity of the population.

Therefore, the purpose of the sociological research is to analyze the national and cultural identity of the population of the Stavropol Territory and to determine the impact of cultural policy carried out in the region on the development of cultural identity of the population.

\section{Literature review}

Modern studies of foreign authors confirm the relevance of the topic and selected research methods.

In his work Unpacking Young People's National Identities: the Role of Ethno-cultural and Religious Allegiances, History and 'Others', author E. Katartzi gives the results of qualitative research conducted in the youth environment. A discursive-discursive analysis of in-depth interview materials illustrates the relationship of ethnicity with religion, as well as the use of historical images and cultural signals to understand the perceived similarities and differences of national groups. The importance of the ethno-cultural and religious identification, which act as a powerful resource for the formation of human self-consciousness, and the importance of empirical research of these processes and their theoretical understanding are emphasized [10].

Researchers Bilali, R., Iqbal, Y., Çelik, A. B. show on the example of representative data comparative characteristics of social processes related to the national 
identity of a person in their work « The role of national identity, religious identity, and intergroup contact on social distance across multiple social divides in Turkey». The authors ' conclusions emphasize the importance of taking into account the content and nature of the national identity of certain groups of society, especially when it comes to negative social practices and conflict situations. It is important to take this into account in social forecasting of intergroup interactions in society [9].

Thus, we can say that researchers assign an important place to the national-cultural identification in the modern society. Moreover, approaches to the study of these social processes have largely similar methodological grounds: the ratio of invariance and variability in determining the characteristics of national-cultural processes, the movement from representative empirical data to theoretical generalizations, the importance of cultural markers in the process of national identification of the individual and group $[3,4]$.

Purpose of work is to conduct a sociological analysis of the national and cultural identity of the population of the Stavropol Territory and to determine the impact of cultural policies on the development of cultural identity.

\section{Methods and material}

In April-May 2018 a survey of residents of the Stavropol Territory on the issues of national and cultural identity and the development of cultural identity of the population of the Stavropol territory was conducted. In total, 643 people took part in it - representatives of 16 municipal and city districts of the Stavropol Territory.

\section{Results}

The national identity of the population is shaped in the conditions of mainly positive social well-being of the residents of Stavropol Territory: over the past 5-7 years, positive trends in the estimates of the life situation of the respondents prevailed. Stability and different levels of improvement were noted by $61.3 \%$ of respondents; $17.8 \%$ of respondents noted different degrees of deterioration; $20.9 \%$ found it difficult to give a definite answer.

The majority of respondents consider themselves Russian by nationality ( $73.4 \%$ of respondents). Armenians are in second place in the national structure of the surveyed population $-9.8 \%$ of the respondents. In the third place - Ukrainians (5.4\% of respondents) and Jews $(4.7 \%$ of respondents). The remaining representatives of the peoples of the North Caucasus (Dargins, Nogais, Karachays, Ossetians, Chechens) and titular nationalities of CIS countries (Belarusians, Georgians, Azerbaijanis) accounted for $6.7 \%$ of the number of respondents.

The structure of the distribution of respondents on the national basis of fathers and mothers basically coincides with the previous generation and in general the national structure of the population of Stavropol Territory is steadily reproduced.

The distribution of respondents ' replies on the nationality of fathers and mothers and other close relatives is presented in table 1 .

Table 1. Distribution of answers to the question «Who are your next of kin by nationality?», (\%)

\begin{tabular}{|c|c|c|c|}
\hline Types of answers & Father & Mother & $\begin{array}{l}\text { Grandmothers } \\
\text { grandfathers }\end{array}$ \\
\hline 1. Russian & 63,8 & 64,7 & 68,8 \\
\hline 2. Ukrainian & 7,7 & 7,7 & 15,8 \\
\hline 3. Armenian & 12,0 & 12,0 & 14,2 \\
\hline 4. Jewish & 2,8 & 3,7 & 5,2 \\
\hline 5. Belarus & 1,5 & 3,4 & 5,5 \\
\hline 6. Nogay & 1,5 & 1,5 & 1,8 \\
\hline 7. Karachai & 2,1 & 1,2 & 3,0 \\
\hline 8. Dargin & 1,2 & 1,2 & 2,1 \\
\hline 9. Chechen & 0,9 & 0,6 & 1,5 \\
\hline 10. Kalmyk & 0,3 & 0,6 & 0,9 \\
\hline 11.Binational (Russian and Ukrainian) & - & - & 4,8 \\
\hline 12. Other & 4,6 & 2,8 & 2,4 \\
\hline 13. Hard to answer & 1,5 & 0,6 & \\
\hline
\end{tabular}

The analysis of the structure of respondents' distribution by nationality of fathers and mothers showed that in general the national structure is practically reproduced coinciding with the previous generation .

The blurriness and lack of clear boundaries between Ukrainian and Russian national identity is evidenced by the fact that a significant proportion of residents of the Stavropol Territory (about 3-5\%) who participated in the survey and indicated that they consider themselves Russian, although their parents (or one of their parents) are Ukrainians.

In addition, it should be noted that having parents of different nationalities, the survey participants consider themselves belonging only to a certain, single nationality. So the answer "binational" was not chosen 
by anyone either in the case of one's own national identity, or in the case of self-identification of parents.

The situation is somewhat different for the older generation of relatives of the respondents - grandparents. Participants of the survey noted the nationality in the older generations and a significantly large proportion of representatives of Ukrainian nationality in the overall structure of the population.

The significance of the question of belonging to a particular nationality for the survey participants can be judged by the results of the responses presented in the following figure.

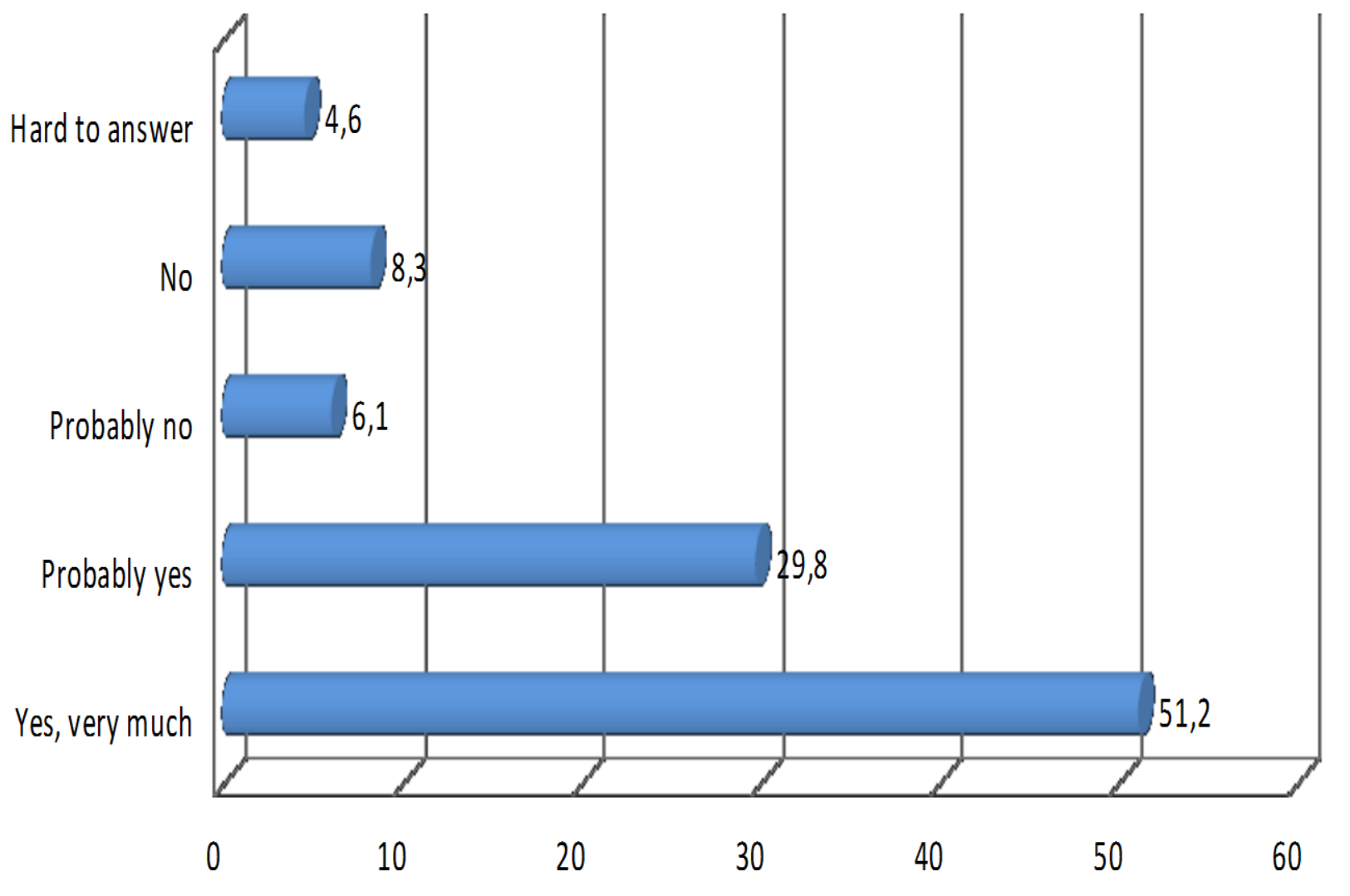

Fig.1. Distribution of answers to the question: «Is it important for you to belong to the nationality which you refer to yourself?», \%

Only $51.2 \%$ of respondents consider belonging to a particular nation to be very important, and another $29.8 \%$ said that such characteristic of their personality is more important for them than not. $14 \%$ of respondents do not see a special role of national identity in their lives, and $4.6 \%$ of respondents found it difficult to give an answer.

In general, we can say only for every second inhabitant of the Stavropol Territory national identification is a very important characteristic of the individual.

The majority of respondents $(87.0 \%)$ noted that it is easier to communicate, read and speak Russian. Thus, the Russian language is widely used for everyday needs, not only by those residents of the Stavropol Territory, who consider themselves Russian by nation (among the respondents $72.3 \%$ ), but also representatives of other nationalities.

The list of languages that the survey participants would like to learn additionally did not include the languages of the peoples of the North Caucasus, Transcaucasia and CIS countries. In general, this suggests that the Russian language is sufficient enough for the international communication to address current issues of life. Among the half of the respondents there are those who want to learn English as one of the most common international languages. Other popular languages are French (24,8\%), Italian (17.9 per cent), Chinese (17.0 per cent), Spanish $(15,5 \%)$, German $(14,2)$.

Speaking about the feelings of respondents when thinking about their nationality, two-thirds pointed to their positive nature, about a third stated about versatility and only $3.1 \%$ noted mainly negative feelings. When thinking about their nationality, they experience pride (45.8\%), enthusiasm (22.4\%), joy (16.4\%), pleasure (12.4\%). $7.9 \%$ of respondents said they did not feel anything. Another $7.6 \%$ found it difficult to answer this question in a certain way. In general, only $12.6 \%$ of respondents indicated various manifestations of negative feelings, including indifference $(4.5 \%)$, disappointment $(3.9 \%)$, shame $(2.7 \%)$, disappointment (1.2\%), displeasure $(0.3 \%)$.

One of the important characteristics of national identification is the religious affiliation of the respondents. $70,7 \%$ of respondents consider themselves religious believers. And most of them consider themselves to be Orthodox.

Only a third of respondents said that they are familiar with the traditions and customs of their nationality. 
Almost half of the respondents indicated that they were generally familiar with the traditions and customs of their nationality. $43.4 \%$ of respondents, as a rule, adhere to the traditions and customs of their nationality. $35.3 \%$ of respondents, some adhere, and some do not. Categorically answered that $11.9 \%$ do not adhere to traditions and customs of the nationality. 9.4\% were unable to answer the question in a certain way.

The existing opinion that national identity is more preserved and manifested in rural settlements with their traditional way of life is only partially confirmed by the survey data. Only 13.7 per cent of the respondents reported about the said tendency. $18,8 \%$ reported about only a slight influence.

Evaluation of opportunities for the development of national culture of respondents showed: $58.2 \%$ of respondents believe that they have all the opportunities for the development of national culture. About a third of respondents, on the contrary, believe that they do not have all the opportunities for the development of national culture. $8.8 \%$ of respondents found it difficult to give a definite answer.

A significant proportion of surveyed participants $(63.9 \%)$ noted that their settlements are working to involve the population in cultural leisure and creative activities. The negative answer was given by $7.6 \%$ of the survey participants. According to $16.4 \%$ of respondents, such work is carried out rather than not. And 12.1\% found it difficult to give a definite answer.

Almost half of the respondents $(42.3 \%)$ said they were aware of the national cultural society operating in the territory of the settlement where they live. $32.5 \%$ noted that they did not know about such activities and another $25.2 \%$ of respondents could not give a definite answer.

\section{Discussion and conclusions}

Among the generalizing conclusions, the most important one is that the national structure of the population of the Stavropol Territory is steadily reproduced. In modern realities, this is an important factor in the sustainable development of the territory.
Key markers of the national and cultural identity: religion and language find proper understanding of their role among representatives of different nationalities.

Cultural institutions and national-cultural societies by their activities have a positive impact on the development of cultural identity of the population of the Stavropol Territory, as evidenced by the results of the study.

The information obtained in the course of the study is important for understanding and determining the vectors of national and cultural policy of the Stavropol Territory and the South of Russia and is reflected in the strategic documents of the regional level.

Monitoring studies of national and cultural identity can serve as an information base for the positive development of the cultural identity of the population of the Stavropol Territory and the entire South of Russia.

\section{References}

1. L. Caricati, International Journal of Intercultural Relations 66, 41-51 (2018)

2. M. Slootman, International Migration 56 (4), 125-139 (2018)

3. A. Miglietta, S. Tartaglia, B. Loera, Revista de Psicologia Social, 1-33 (2018)

4. M.J. Coleman, T.M. Harris, K.L. Bryant, C. ReifStice, Journal of International and Intercultural Communication, 11 (3), 173-191 (2018)

5. Ş. Yitmen, M. Verkuyten, Journal of Community and Applied Social Psychology, 28 (4), 230-243 (2018)

6. F. Fleischmann, K. Phalet, Journal of Cross-Cultural Psychology, 49, 1, 44-61 (2018)

7. V. Galyapina, N. Lebedeva, F.J.R van de Vijver, Journal of Cross-Cultural Psychology, 49 (6), 976-992 (2018)

8. N. Lewin-Epstein, Y. Cohen, Journal of Ethnic and Migration Studies, 1-20 (2018)

9. R. Bilali, Y. Iqbal, A.B Çelik, International Journal of Intercultural Relations, 65, 73-85 (2018)

10. E. Katartzi, History and 'Others' Young, 26 (3), 215231 (2018) 